DOI: 10.20472/IAC.2018.036.033

BENARD KWAME OPPONG-KUSI

University of Tsukuba, Japan

KENICHI MATSUI

University of Tsukuba, Japan

ADWOA OFORIWAA ANTWI

University of Tsukuba, Japan

\title{
THE THEMATIC ANALYSIS OF LAND DISPUTES IN GHANA: THE CASE OF THE DORMAA TRADITIONAL AREA
}

\begin{abstract}
:
In Ghana, land disputes are ubiquitous largely because of its unique land tenure, governance, and management practices. Enduring land disputes are costly and have serious implications on the regional economic development and food security. In some parts of the country, land dispute issues took nearly three decades to reach court judgments. Ghana's land disputes have been handled by both modern courts and traditional courts. This paper examines Ghana's land dispute resolution mechanism in the Dormaa traditional area. We analyzed 11 court case proceedings, including those of High and Appeal courts. Our analysis found three major factor that triggered land disputes at court: (1) land trespassing (2) lack of clear ownership documentation (3) bias towards traditional owners or defendant. After discussing these with details, we recommend (1) land ownership documentation (2) the creation of more ADR centers.
\end{abstract}

\section{Keywords:}

Land Dispute, Land Tenure, Dispute Resolution 